\title{
A COMPARATIVE STUDY TO EVALUATE THE EFFICACY OF AUTOLOGOUS FIBRIN (BLOOD), FIBRIN GLUE AND SUTURES IN CONJUNCTIVAL AUTOGRAFT FOR PTERYGIUM EXCISION
}

\author{
Shanti Pandey1, Vivekanand Satyawali², Govind Singh Titiyal33, Nitin Mehrotra4, Anshika Kashyap5, Pravin Prakash Hankare ${ }^{6}$ \\ ${ }^{1}$ Associate Professor, Department of Ophthalmology, Government Medical College, Haldwani, Nainital, Uttarakhand. \\ ${ }^{2}$ Associate Professor, Department of Medicine, Government Medical College, Haldwani, Nainital, Uttarakhand. \\ 3 Professor, Department of Ophthalmology, Government Medical College, Haldwani, Nainital, Uttarakhand. \\ ${ }^{4}$ Assistant Professor, Department of Ophthalmology, Government Medical College, Haldwani, Nainital, Uttarakhand. \\ 53rd Year Postgraduate, Department of Ophthalmology, Government Medical College, Haldwani, Nainital, Uttarakhand. \\ ${ }^{6} 2^{\text {nd }}$ Year Postgraduate, Department of Ophthalmology, Government Medical College, Haldwani, Nainital, Uttarakhand.
}

\begin{tabular}{l}
\hline ABSTRACT \\
BACKGROUND \\
Pterygium, a growth of fibrovascular tissue on the cornea, which appears to be continuous with conjunctiva. Its treatment is \\
mainly surgical.
\end{tabular}

\section{AIMS AND OBJECTIVES}

To compare three surgical techniques in management of pterygium.

\section{STUDY DESIGN}

Prospective randomised interventional study.

\section{MATERIALS AND METHODS}

The study was conducted from November 2013 to November 2015 at the Department of Ophthalmology, GMC, Haldwani, Uttarakhand. All the patients of primary nasal pterygium who came in OPD were selected for surgical intervention. A total number of 75 eyes (75 patients) undergoing pterygium excision with conjunctival autograft were taken and randomly allocated to three groups: Autograft using autologous blood (Group A, 23 patients), Autograft using fibrin glue (Group F, 21 patients) and Autograft using sutures (Group S, 31 patients). The three groups were compared for: duration of surgery, postoperative discomfort and complications.

\section{RESULTS}

The duration of surgery was longer in group A $(23.73 \pm 1.05 \mathrm{~min}$.) and S $(25.51 \pm 3.01 \mathrm{~min}$.) as compared to group F (20.22 \pm 0.8 $\mathrm{min}$ ). In Group S, 15 patients (48.38\%) reported moderate postoperative discomfort on day 1 and also for the longest duration. Graft oedema was comparable in the three groups. Graft displacement was seen in 1 patient of group A (4.34\%).

\section{CONCLUSION}

Three surgical techniques used in study are equally effective, but have their own merits and demerits. Postoperative discomfort and suture related complication remains a drawback in suture group. Fibrin glue possesses less complication, but affordability is an issue. Autologous blood is cost effective, has less postoperative discomfort, but graft displacement remains a concern.

\section{KEYWORDS}

Pterygium Management, Surgical Technique, Comparative Study.

HOW TO CITE THIS ARTICLE: Pandey S, Satyawali V, Titiyal GS, et al. A comparative study to evaluate the efficacy of autologous fibrin (blood), fibrin glue and sutures in conjunctival autograft for pterygium excision. J. Evolution Med. Dent. Sci. 2016;5(78): 58435847, DOI: $10.14260 /$ jemds/2016/1317

\section{INTRODUCTION}

Pterygium is a degenerative condition of subconjunctival tissue which proliferates as vascularised granulation tissue to invade the cornea, damaging the superficial layers of stroma and Bowman's membrane, may encroach upon pupillary area. As a result of tissue fibrosis, it may lead to alteration of corneal curvature leading to astigmatism and corneal opacity. Its prevalence rate varies from $0.3 \%$ to $29 \%$ in various parts of the world. ${ }^{1}$

Financial or Other, Competing Interest: None.

Submission 15-08-2016, Peer Review 08-09-2016,

Acceptance 16-09-2016, Published 29-09-2016.

Corresponding Author:

Dr. Shanti Pandey,

Associate Professor,

Department of Ophthalmology,

Type 4, K2, Medical College Campus,

Haldwani, Nainital, Uttarakhand.

E-mail: drshantipandey@gmail.com

DOI: $10.14260 /$ jemds/2016/1317
Medical treatment of symptomatic patients involves tear substitutes, and topical steroids, and sunglasses (to reduce UV exposure). ${ }^{2}$

Pterygia warrant surgical treatment when they cause discomfort (Not responsive to conservative therapy), encroach upon the visual axis, induce significant astigmatism, or become cosmetically bothersome. A variety of surgical techniques have been developed.

Recurrence rate is very high after simple excision (Bare sclera), main challenge is prevention of its recurrence. ${ }^{3}$ The $50 \%$ reoccur within 4 months of excision and nearly all within 1 year. $^{4}$ Beta-radiation applied postoperatively to the pterygium base was popular for many years, but is associated with late scleral necrosis. ${ }^{5}$

Currently, the most widely used techniques are conjunctival autografting, amniotic membrane transplantation, and mitomycin-C application - either pre, intra, or postoperatively.5,6 Fibrin-based glues have been used 
to minimise operating time and discomfort associated with sutures and to reduce the amount of suturing required. ${ }^{7}$

In recent past, the debate over best approach to surgery was centred on sutures and fibrin glue to affix the conjunctival graft. Former requires good surgical skill and is associated with high postoperative suture related discomfort. Biodegradable nature of glue leads to less inflammation, but its high cost, risk of transmission of prion disease and anaphylaxis are its are main limiting factors. ${ }^{8}$

The technique of using patient's own blood (autologous blood) to fix graft to recipient site reduces the operating time, suture related postoperative complications, overcomes complications of glue and reduces the economic burden.

\section{AIMS AND OBJECTIVES}

1. To compare duration of surgery in three groups.

2. To compare postoperative discomfort in three groups.

3. To compare the postoperative complications in three groups.

\section{MATERIALS AND METHODS}

The study was conducted at the Department of Ophthalmology, Government Medical College, HaldwaniNainital, Uttarakhand. It was a prospective, randomised, interventional study during a period of 2 years from November 2013 to November 2015.

A total number of 75 eyes (of 75 patients) presenting to the outpatient department (OPD) needing surgical intervention were selected. Informed written consent was taken from the patients before performing the surgery. Patients were randomly allocated to three groups: Group A: autograft using autologous blood (23 patients); Group F: autograft using fibrin glue (21 patients); Group S: autograft using sutures (31 patients).

\section{Inclusion Criteria}

1. Encroachment upon visual axis.

2. Significant decrease in visual acuity due to astigmatism.

3. Causing recurrent irritation.

4. Cosmetically bothersome to the patient.

5. Patients older than 20 years and younger than 60 years.

\section{Exclusion Criteria}

1. Temporal pterygium.

2. Recurrent pterygium, Atrophic pterygium.

3. Pseudopterygium.

4. Patients on anticoagulants.

5. Patients with pre-existing glaucoma.

6. History of previous ocular surgery or trauma.

After surgical intervention, eyes were patched for 24 hours in Group S and Group F and for 48 hours in Group A.

Postoperatively, topical antibiotics, steroids and lubricants were given. Followup visits were done on $1^{\text {st }}$ week, 1, 3 and 6 months.

The three groups were compared for: duration of surgery, postoperative discomfort and complications. The complications included recurrence, graft oedema, graft stability and suture related complications like granuloma formation, suture abscess, pyogenic granuloma.
Mean duration of surgery was noted in the three groups and it was calculated from the time putting the traction suture to the removal of lid speculum.

Postoperative discomfort was graded on visual analogue scale (VAS) as mild (1-3 score on numeric VAS scale), moderate (4-6 score on numeric VAS scale), and severe (7-10 score on numeric VAS scale).

Graft stability was assessed on day 1 in Group S and Group $\mathrm{F}$ and day 2 in Group A.

\section{RESULTS AND OBSERVATIONS}

A total number of 75 eyes (of 75 eyes) presenting to the outpatient department (OPD) needing surgical intervention were selected. Patients were randomly allocated to three groups: Group A: autograft using autologous blood (23 patients), Group F: autograft using fibrin glue (21 patients), Group S: autograft using sutures (31 patients).

Out of the 75 patients, 29 were males and 46 females showing a female predilection (Table 1).

\begin{tabular}{|c|c|c|}
\hline Group & Male & Female \\
\hline $\begin{array}{c}\text { Group A } \\
\text { (autologous blood) }\end{array}$ & $11(47.82 \%)$ & $12(52.18 \%)$ \\
\hline $\begin{array}{c}\text { Group S } \\
\text { (with suture) }\end{array}$ & $10(47.61 \%)$ & $21(52.29 \%)$ \\
\hline Group F (fibrin glue) & $8(32.25 \%)$ & $13(67.75 \%)$ \\
\hline Total & $29(38.66 \%)$ & $46(61.34 \%)$ \\
\hline \multicolumn{3}{|c|}{$\begin{array}{c}\text { Table 1: Distribution according to Gender } \\
\text { in the Three Groups }\end{array}$} \\
\hline
\end{tabular}

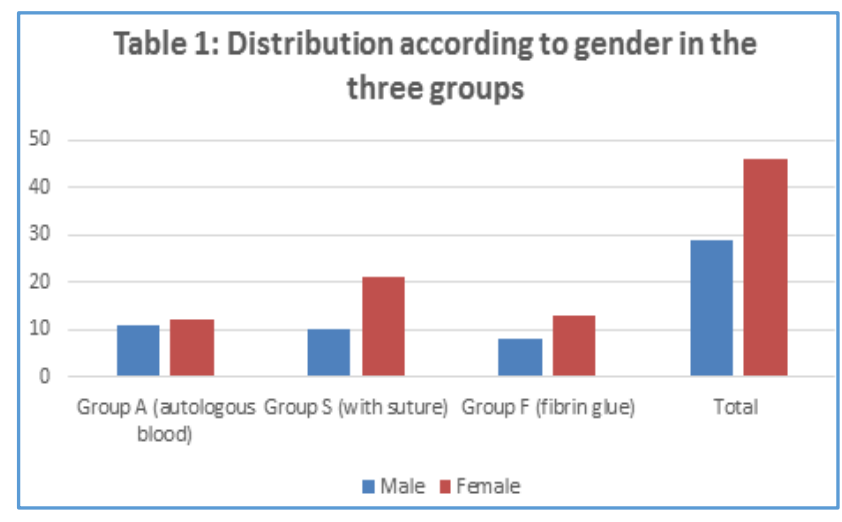

43 patients (57.34\%) in the study group had an occupation in outdoor/field work (Table 2).

\begin{tabular}{|c|c|c|}
\hline Occupation & No. of Cases & $\mathbf{\%}$ \\
\hline Field worker/labourer & 43 & 57.34 \\
\hline Housewife & 11 & 14.66 \\
\hline Study/computer work & 4 & 5.34 \\
\hline Business & 6 & 8.00 \\
\hline Others & 11 & 14.66 \\
\hline Table 2: Distribution according to Occupation \\
\hline
\end{tabular}


Table 2: Distribution according to occupation No.

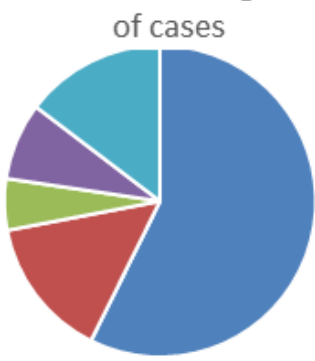

- Field worker/labourer " Housewife "Study/computer work "Business " Others

On $1^{\text {st }}$ postoperative day, as many as 15 (48.38\%) patients in group $\mathrm{S}$ reported moderate discomfort, whereas only mild discomfort was reported by $16(69.56 \%)$ patients in group A and by 12 (57.14\%) in group F (Table 3.1, 3.2 and 3.3).

Most of patients in all groups did not report any discomfort beyond $1^{\text {st }}$ week of followup. Severe and moderate discomfort was not reported in any group beyond $1^{\text {st }}$ week of followup.

In group $\mathrm{A}$ and $\mathrm{F}$, no patient reported discomfort after 1month duration, but $2(6.46 \%)$ patients in group $\mathrm{S}$ reported mild discomfort as long as 3 months.

At 6 months followup, no patient reported any discomfort.

\begin{tabular}{|c|c|c|c|c|c|}
\hline $\begin{array}{c}\text { No } \\
\text { Discomfort }\end{array}$ & $\begin{array}{c}2 \\
(8.69 \%)\end{array}$ & $\begin{array}{c}20 \\
(86.96 \%)\end{array}$ & $\begin{array}{c}23 \\
(100 \%)\end{array}$ & $\begin{array}{c}23 \\
(100 \%)\end{array}$ & $\begin{array}{c}23 \\
(100 \%)\end{array}$ \\
\hline Mild & $\begin{array}{c}16 \\
(69.56 \%)\end{array}$ & $3(13.04 \%)$ & 0 & 0 & 0 \\
\hline Moderate & $\begin{array}{c}3 \\
(13.04 \%)\end{array}$ & 0 & 0 & 0 & 0 \\
\hline Severe & $2(8.69 \%)$ & 0 & 0 & 0 & 0 \\
\hline Table 3.1: Comparison of Postoperative Discomfort in \\
Autologous Blood Group (Group A) \\
\hline
\end{tabular}

\begin{tabular}{|c|c|c|c|c|c|}
\hline $\begin{array}{c}\text { Post-op } \\
\text { discom- } \\
\text { fort }\end{array}$ & Day 1 & 1 week & 1 month & $\begin{array}{c}3 \\
\text { months }\end{array}$ & $\begin{array}{c}\mathbf{6} \\
\text { months }\end{array}$ \\
\hline $\begin{array}{c}\text { No } \\
\text { discom- } \\
\text { fort }\end{array}$ & $\begin{array}{c}2 \\
(6.45 \%)\end{array}$ & $\begin{array}{c}4 \\
(12.90 \%)\end{array}$ & $\begin{array}{c}28 \\
(90.32 \%)\end{array}$ & $\begin{array}{c}29 \\
(93.54 \%)\end{array}$ & $\begin{array}{c}31 \\
(100 \%)\end{array}$ \\
\hline Mild & $\begin{array}{c}8 \\
(25.80 \%)\end{array}$ & $\begin{array}{c}15 \\
(48.38 \%)\end{array}$ & $\begin{array}{c}3 \\
(9.68 \%)\end{array}$ & $\begin{array}{c}2 \\
(6.46 \%)\end{array}$ & 0 \\
\hline Moderate & $\begin{array}{c}15 \\
(48.38 \%)\end{array}$ & $\begin{array}{c}11 \\
(35.48 \%)\end{array}$ & 0 & 0 & 0 \\
\hline Severe & $6(19.35 \%)$ & $1(3.22 \%)$ & 0 & 0 & 0 \\
\hline \multicolumn{7}{|c|}{ Table 3.2: Comparison of Postoperative Discomfort } \\
in Suture Group (Group-S) \\
\hline
\end{tabular}

\begin{tabular}{|c|c|c|c|c|c|}
\hline $\begin{array}{c}\text { Post-op } \\
\text { discom- } \\
\text { fort }\end{array}$ & Day 1 & 1 week & $\begin{array}{c}\mathbf{1} \\
\text { month }\end{array}$ & $\begin{array}{c}\mathbf{3} \\
\text { months }\end{array}$ & $\begin{array}{c}\mathbf{6} \\
\text { months }\end{array}$ \\
\hline $\begin{array}{c}\text { No } \\
\text { discom- } \\
\text { fort }\end{array}$ & $\begin{array}{c}6 \\
(28.57 \%)\end{array}$ & $\begin{array}{c}18 \\
(85.72 \%)\end{array}$ & $\begin{array}{c}21 \\
(100 \%)\end{array}$ & $\begin{array}{c}21 \\
(100 \%)\end{array}$ & $\begin{array}{c}21 \\
(100 \%)\end{array}$ \\
\hline Mild & $\begin{array}{c}12 \\
(57.14 \%)\end{array}$ & $\begin{array}{c}3 \\
(14.28 \%)\end{array}$ & 0 & 0 & 0 \\
\hline $\begin{array}{c}\text { Moder- } \\
\text { ate }\end{array}$ & $\begin{array}{c}3 \\
(14.28 \%)\end{array}$ & 0 & 0 & 0 & 0 \\
\hline Severe & 0 & 0 & 0 & 0 & 0 \\
\hline \multicolumn{7}{|c|}{ Table 3.3: Comparison of Postoperative Discomfort } \\
in Fibrin Glue (group F) \\
\hline
\end{tabular}

Graft displacement was seen in 1 (4.34\%) patient in group $\mathrm{A}$ and none in the other 2 groups (Table 4).
Graft oedema occurred in comparable ratio in group A and S, i.e. $43.47 \%, 45.16 \%$, but it was comparatively less i.e. $38.09 \%$ in group $\mathrm{F}$.

Recurrence occurred in 1 patient in each of the 3 groups. There was 1 case $(3.22 \%)$ of suture related granuloma in group $\mathrm{S}$ at one week followup.

\begin{tabular}{|c|c|c|c|}
\hline Complication & $\begin{array}{c}\text { Group A } \\
\text { (Autologous } \\
\text { Blood) }\end{array}$ & $\begin{array}{c}\text { Group S } \\
\text { (with } \\
\text { Suture) }\end{array}$ & $\begin{array}{c}\text { Group F } \\
\text { (Fibrin } \\
\text { Glue) }\end{array}$ \\
\hline $\begin{array}{c}\text { Graft } \\
\text { displacement }\end{array}$ & $1(4.34 \%)$ & 0 & 0 \\
\hline Graft Oedema & $10(43.47 \%)$ & $14(45.16 \%)$ & $8(38.09 \%)$ \\
\hline Recurrence & $1(4.34 \%)$ & $1(3.22 \%)$ & $1(4.76 \%)$ \\
\hline $\begin{array}{c}\text { Others } \\
\text { (Suture Related) }\end{array}$ & 0 & $1(3.22 \%)$ & 0 \\
\hline \multicolumn{3}{|c|}{ Table 4: Distribution of Complications in the three } \\
Groups including Recurrence \\
\hline
\end{tabular}

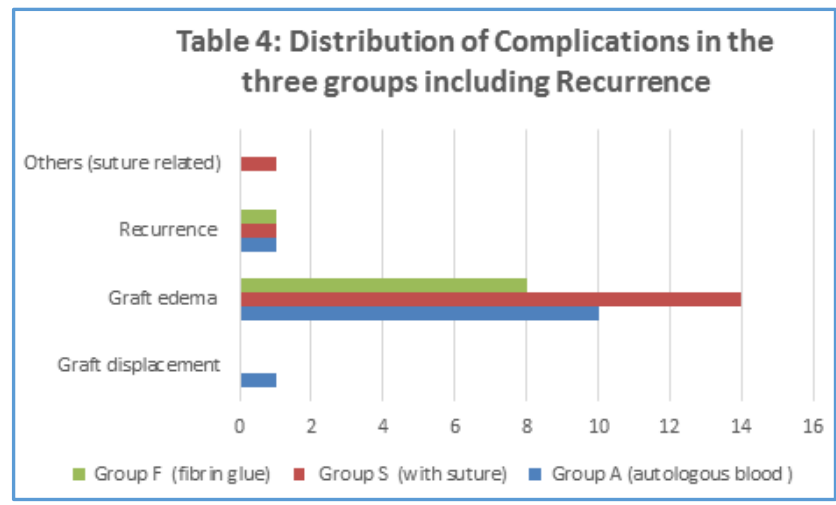

Mean duration of surgery in Group A was $23.73 \pm 1.05$ minutes while in group $S$ it was $25.51 \pm 3.01$ minutes. The mean duration was less in group F (20.22 \pm 0.8 minutes) as compared to the other groups (Table 5).

\begin{tabular}{|c|c|}
\hline Groups & $\begin{array}{l}\text { Mean Duration of } \\
\text { Surgery (Minutes) }\end{array}$ \\
\hline Group A (autologous blood) & 23.73 \\
\hline Group S (with suture) & 25.51 \\
\hline Group F (fibrin glue) & 20.22 \\
\hline \multicolumn{2}{|c|}{ Table 5: Mean Duration of Surgery in the three Group } \\
\hline
\end{tabular}

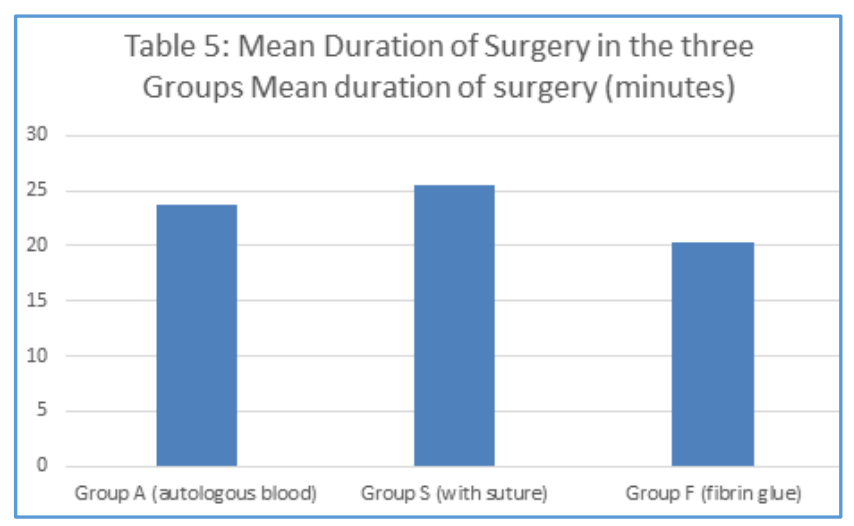

\section{DISCUSSION}

Many previous studies suggest that the prevalence of pterygium is higher in males (Hilgers $\mathrm{JH}$ et al). But in present study, we have seen a higher prevalence of pterygium in 
females (61.34\%). Reason for higher prevalence could be greater UV light and dust exposure due to outdoor work of women in hilly region of Kumaon to earn livelihood.

Study by $\mathrm{Lu} \mathrm{P}$ et $\mathrm{al}^{9}$ reported a higher prevalence of pterygium in female than male, which he suggested could be due to Tibetan lifestyle where women had mainly rural and outdoor work. Most of patients in the present study were from middle age group, (mean age in group A being 36.5 years; in group $\mathrm{S}, 41.97$ years; in group $\mathrm{F}, 32.76$ years).

In present study, most of the patients were field workers/labourers (57.34\%). Mackenzie FD et al reported that there are 4 to 11 times more chances of having pterygium in persons working outdoors, exposed to sun and dust. ${ }^{10}$

Management of pterygium remains challenging. Medical treatment in the form of topical NSAIDS, steroids, lubricants and Injection of anti-VEGF agents have limited role. Till date, surgical management remains treatment of choice. But there are problems with surgical treatment also. Bare sclera left behind after simple excision of pterygium is associated with recurrence rates of $30 \%$ to $70 \%$. With adjunctive measures such as topical Thiotepa, 5-fluorouracil, or mitomycin-C, the recurrence rate is lower but there is a high risk of complications with these agents.

Conjunctival autografting after pterygium excision is associated with lower recurrence rates (2\% to $9 \%$ ) and relatively few sight threatening complications.11,12

Different methods of securing graft to scleral bed are in practice now. But securing the graft with sutures is the most commonly performed procedure. Koranyi and associates ${ }^{12}$ were the first to report the use of fibrin glue. Risk of transmission of prion disease and risk of anaphylaxis in susceptible individuals ${ }^{8}$ are main limiting factors in glue method of treatment.

In the present study, we have compared the three methods of surgical management in view of postoperative discomfort. On $1^{\text {st }}$ postoperative day, as many as 15 (48.38\%) patients in group $\mathrm{S}$ reported moderate discomfort, whereas only mild discomfort was reported by $16(69.56 \%)$ patients in group A and by $12(57.14 \%)$ in group F. Most of the patients in all 3 groups did not report discomfort beyond 1st week of followup. Several other studies also reveal similar discomfort in postoperative period. (SAM Elwan et al, P Peeush et al ${ }^{13}$, D de Wit et al $^{3}$ ).

Graft displacement is a major concern in grafts fixed by autologous blood in immediate postoperative period and most of them occur within 24 to 48 hours of surgery. Graft usually displaces due to undue rubbing of operated eye due to foreign body sensation, which can be prevented by proper counselling. Graft retraction at its bed is also an issue with this technique, but appropriately thin graft of adequate size avoids this complication in most of the patients. In present study, graft was displaced in 1 patient (4.34\%) and patient gave the history of rubbing the eye. Nisha Dulani et al also reported graft displacement in only $3.39 \%$ of the patients.

Graft oedema occurred in comparable ratio in group A and S i.e. $43.47 \%, 45.16 \%$, but it was comparatively less i.e. $38.09 \%$ in group $F$. This reduced after giving topical steroids in tapering doses. In study of Celeva Markovaskaet al ${ }^{14}$ graft oedema was present in $22.5 \%$ of cases in Suture group. In our study this is greater. Type of pterygium and intraoperative manipulation may be responsible for greater graft oedema.
At the end of 6 months, recurrence was seen in 1 patient in each of the 3 groups i.e. $4.34 \%$ in group A, 3.22\% in group S and $4.76 \%$ in group F. Similar studies by Malik KPS et al ${ }^{15}$ and Nisha Dulani et al also correlate with recurrence rates of present study.

Mean duration of surgery in Group A was $23.73 \pm 1.05$ minutes while in group $S$ it was $25.51 \pm 3.01$ minutes. The mean duration was less in group F (20.22 \pm 0.8 minutes) as compared to the other groups. In a study by SAM Elwan et al ${ }^{15}$, mean operating time was 24 minutes in Autologous blood group and 28.64 minutes in Suture group which correlates with present study.

\section{CONCLUSION}

Postoperative discomfort and suture related complications remain the drawback in suture group.

The technique for graft fixation using fibrin glue poses less complications, but affordability is an issue in our patients, who are mainly field workers and labourers. Fibrin glue being costly is not affordable by most of the patients in our region.

Graft fixation using autologous blood is cost effective, has less postoperative discomfort and no risk of viral disease transmission, but graft displacement remains a concern of this technique, though the overall incidence of this complication is very less.

The fact is that numerous surgical techniques exist for the surgical treatment, but the point is that no approach is universally successful.

\section{REFERENCES}

1. Hilgers JH. Pterygium on the island of Aruba. Amsterdam klein offset drukkerjj poortpers NV. 1959.

2. Kanski JJ, Bowling B. Clinical ophthalmology: a systematic approach. 7th edn. Edinburgh, New York: Elsevier Saunders 2011.

3. de Wit D, Athanasiadis I, Sharma A, et al. Sutureless and glue-free conjunctival autograft in pterygium surgery: a case series. Eye (Lond) 2010;24(9):1474-7.

4. Hirst LW, Sebban A, Chant D. Pterygium recurrence time. Ophthalmology 1994;101(4):755-8.

5. Ma DH, See LC, Liau SB, et al. Amniotic membrane graft for primary pterygium: comparison with conjunctival autograft and topical mitomycin $\mathrm{C}$ treatment. $\mathrm{Br} \mathrm{J}$ Ophthalmol 2000;84(9):973-8.

6. Chen PP, Ariyasu RG, Kaza V, et al. A randomized trial comparing mitomycin $\mathrm{C}$ and conjunctival autograft after excision of primary pterygium. Am J Ophthalmol 1995;120(2):151-60.

7. Uy HS, Reyes JM, Flores JD, et al. Comparison of fibrin glue and sutures for attaching conjunctival autografts after pterygium excision. Ophthalmology 2005;112(4):667-71.

8. Lu P, Chen X, Kang Y, et al. Pterygium in Tibetans: a population-based study in China. Clin Exp Ophthalmol 2007;35(9):828-33.

9. Mackenzie FD, Hirst LW, Battistutta D, et al. Risk analysis in the development of pterygia. Ophthalmology 1992; 99(7):1056-61.

10. Kenyon KR, Wagoner MD, Hettinger ME. Conjunctival autograft transplantation for advanced and recurrent pterygium. Ophthalmology 1985;92(11):1461-70. 
11. Allan BD, Short P, Crawford CJ, et al. Pterygium excision with conjunctival autografting: an effective and safe technique. Br J Ophthalmol 1993;77(11):698-701.

12. Koranyi G, Seregard S, Kopp ED. Cut and paste: a no suture, small incision approach to pterygium surgery. $\mathrm{Br} \mathrm{J}$ Ophthalmol 2004;88(7):911-914.

13. Peeush P, Sarkar S. A comparative study of pterygium excision using autologous blood versus sutures: a study from remote eastern Bihar, India. Ophthalmology Research: An International Journal 2015;3(1):28-32. Article no 2015.005.
14. Markovska CV, Babic SG, Jankuloska ZM. Comparative study of pterygium surgery. Prilozi 2011;32(2):273-87.

15. Malik KP, Goel R, Gupta A, et al. Efficacy of sutureless and glue free limbal conjunctival autograft for primary pterygium surgery. Nepal J Ophthalmol 2012;4(2):230-5. 